\title{
Oxidation behaviour of the near $\alpha$-titanium alloy IMI 834
}

\author{
K V SAI SRINADH and VAKIL SINGH* \\ Centre of Advanced Study, Department of Metallurgical Engineering, Institute of Technology, \\ Banaras Hindu University, Varanasi 221005 , India
}

MS received 27 February 2004

\begin{abstract}
Oxidation behaviour of the near $\alpha$-titanium alloy IMI 834 was investigated over a range of temperatures, from $600-800^{\circ} \mathrm{C}$, in air. Specimens were solution-treated in the $\alpha+\beta$ and $\beta$ phase fields for $1 \mathrm{~h}$ and $1 / 2 \mathrm{~h}$, respectively and cooled in air to room temperature. The solution treated samples were subjected to stabilization treatment at $7^{\circ} 0^{\circ} \mathrm{C}$ for $2 \mathrm{~h}$, followed by cooling in air. Oxidation behaviour of these samples was studied from $600-800^{\circ} \mathrm{C}$ in air, for $50 \mathrm{~h}$. The morphology of the scales formed was examined by SEM and the phases present in the scales were characterized by $\mathrm{X}$-ray diffraction. While there was little oxidation at $600^{\circ} \mathrm{C}$, the rate of oxidation increased at higher temperatures. In general, the rate of oxidation was found to be more in the $\alpha+\beta$ treated condition than that in the $\beta$ treated one. The results are discussed in terms of the characteristics of the oxide film formed under different conditions.
\end{abstract}

Keywords. Near $\alpha$-titanium alloy IMI 834; thermogravimetric studies; activation energy; oxidation behaviour; surface morphology.

\section{Introduction}

Efficient aero engines demand high temperature materials with high specific strength and resistance against creep, fatigue and environmental degradation at elevated temperature. Mostly nickel based super alloys are used for hot zones of compressor of advanced gas turbines because of their superior high temperature mechanical properties and adequate resistance against environmental degradation. Since the specific strength of titanium alloys like IMI 834 is considerably higher than those of nickel based super alloys up to $600^{\circ} \mathrm{C}$, they are considered as potential materials for structural components like compressor discs and blades of advanced gas turbine engines of light weight aircrafts.

One of the major factors limiting the life of titanium alloys in service is their degradation due to gaseous environments, in particular, the one containing oxygen, especially at elevated temperatures, during the long term use. Interaction of titanium alloys with oxygen not only causes loss of the material by formation of oxides, but also causes embrittlement in the subsurface zone of the component due to oxygen enrichment (Wiedemann et al 1987; Liu and Welsch 1988; Leyens et al 1996).

Oxidation behaviour of titanium and titanium alloys has been studied by several investigators, at high temperatures i.e over $700^{\circ} \mathrm{C}$, due to the ease of measurement in the change of weight of the specimen. The oxidation data of high temperature range $\left(>700^{\circ} \mathrm{C}\right)$ have been transpo-

\footnotetext{
*Author for correspondence
}

sed to the range of low temperature, $400-600^{\circ} \mathrm{C}$, the region of actual and potential working temperature. However, it was observed by Champin (1980) that the results obtained by extrapolation were different from the actual behaviour in the case of titanium alloys. Therefore, Coddet et al (1980) extended the previous studies on industrial and experimental alloys including specific binary alloys, in the region of low temperature, in order to examine the effect of different alloying elements. It was observed that alloying elements $\mathrm{V}$ and $\mathrm{Si}$ considerably modified the oxidation resistance of titanium. While the effect of $\mathrm{Si}$ was found to be favourable, that of $\mathrm{V}$ was highly unfavourable, Al and $\mathrm{Zr}$ were found to have slightly favourable effect; whereas other alloying elements like Mo and Sn have no significant effect.

The kinetics of oxidation of the titanium alloys $\mathrm{Ti}-$ 6Al-4V and Ti-6Al-5Zr-0.5Mo-0·25Si (IMI 685) was studied by Magdalena (1998), in air and oxygen, over a range of temperature from $400-600^{\circ} \mathrm{C}$, at pressures of $50 \mathrm{~mm}$ and $150 \mathrm{~mm} \mathrm{Hg}$. It was observed that with increase in time and temperature of oxidation, variation in the rate of oxidation was less dependent on pressure. Also a comparative study of oxidation behaviour of three titanium alloys: Ti-6Al-4V, IMI685, and IMI550, showed linear increase in weight at $600^{\circ} \mathrm{C}$ in air and oxygen. The rate of oxidation of $\mathrm{Ti}-6 \mathrm{Al}-4 \mathrm{~V}$, however, was relatively higher due to the presence of vanadium. The activation energy for oxidation in oxygen was estimated to be $30 \pm 3 \mathrm{kcal} /$ mole $(126 \pm 13 \mathrm{~kJ} / \mathrm{mole})$.

Oxidation behaviour of selected titanium alloys, in the range of low temperature from $400-600^{\circ} \mathrm{C}$, has been studied by Bania (1988). It was observed that the kinetics 
of oxidation of titanium alloys had a complex character and was dependent on the kind and concentration of the alloying elements in the binary or multi component system. From the kinetics of oxidation of the individual alloys, a positive influence of the alloying elements $\mathrm{Al}, \mathrm{Si}$ and $\mathrm{Zr}$ was observed when there was high content of these elements in the alloys.

Oxidation behaviour of polycrystalline Kroll titanium at elevated temperatures, was studied by Simon et al (1980) in oxygen at partial pressure of $1.9 \times 10^{-5}$ torr. It was observed that below $700^{\circ} \mathrm{C}$, oxidation behaviour was parabolic within a short span of time, however, at higher temperatures, it became linear for several hours. Oxidation behaviour of the alloys $\mathrm{Ti} 36 \mathrm{Al}$, Ti $35 \mathrm{Al}-0 \cdot 1 \mathrm{C}$, Ti 35Al$1 \cdot 4 \mathrm{~V}-0 \cdot 1 \mathrm{C}$ and $\mathrm{Ti} 35 \mathrm{Al} 5 \mathrm{Nb}-0 \cdot 1 \mathrm{C}$ (mass\%) has been studied by Becker et al (1992) in air and oxygen between $700^{\circ} \mathrm{C}$ and $1000^{\circ} \mathrm{C}$, with major emphasis at $900^{\circ} \mathrm{C}$. It was observed that an oxide scale, consisting of two layers, one growing outward and the other growing inward, had formed. The outward growing part of the scale consisted mainly of $\mathrm{TiO}_{2}$, while the inward growing part was composed of a mixture of $\mathrm{TiO}_{2}$ and $\alpha-\mathrm{Al}_{2} \mathrm{O}_{3}$. Oxidation in air can also lead to formation of nitrides beneath the oxide scale. In general, nitridation was found to be detrimental for oxidation resistance and consequently oxidation was generally more rapid in air than in oxygen.

Many titanium alloys have been developed for aerospace applications where mechanical properties are the primary consideration. In industrial applications, however, corrosion resistance is the most important property. Titanium and its alloys provide excellent resistance to general localized attack under most oxidizing, neutral and reducing conditions. Corrosion resistance of titanium is due to a stable, protective, strongly adherent oxide film. This film forms instantly when a fresh surface is exposed to air or moisture. The growth of the film is accelerated under strongly oxidizing conditions, such as heating in air, anodic polarization in an electrolyte or exposure to oxidizing agents such as $\mathrm{HNO}_{3}$ etc (Andreeva 2003). The composition of the film varies from $\mathrm{TiO}_{2}$ at the surface to $\mathrm{Ti}_{2} \mathrm{O}_{3}$, TiO towards the metal interface.

Table 1. Chemical composition of the alloy IMI 834 (mass\%).

\begin{tabular}{cccccccc}
\hline $\mathrm{Al}$ & $\mathrm{Sn}$ & $\mathrm{Zr}$ & $\mathrm{Nb}$ & $\mathrm{Mo}$ & $\mathrm{Si}$ & $\mathrm{C}$ & $\mathrm{Ti}$ \\
\hline 5.07 & 3.08 & 3.45 & 0.66 & 0.31 & 0.2 & 0.04 & $\mathrm{Bal}$. \\
\hline
\end{tabular}

Alloys like Ti6242, Ti6246, Ti17, IMI 829, IMI 834, Ti 1100 are characterized as oxidation resistant titanium alloys (Holt-Walton and Hill 2002). Among all these alloys IMI 834 and TIMETAL 1100 are designed for service temperature up to $600^{\circ} \mathrm{C}$. Oxidation behaviour of the near alpha-titanium alloys IMI 834 and TIMETAL 1100 has been studied by Leyens et al (1996) at $750^{\circ} \mathrm{C}$ for $100 \mathrm{~h}$, in air. It was observed that oxidation of the alloy IMI 834 was less dependent on its microstructure than that of the alloy TIMETAL 1100. Both the alloys were found to be resistant to oxidation with lamellar structure but least with the globular structure. Scale adherence was found to be markedly influenced by the formation of $\mathrm{Ti}_{3} \mathrm{AlN}$ during the period of oxidation.

The present investigation pertains to oxidation behaviour of the high temperature near $\alpha$ titanium alloy IMI 834 in air over a wider range of temperature from 600 $800^{\circ} \mathrm{C}$, following solution treatment in the $\alpha+\beta$ and $\beta$ phase fields for $1 \mathrm{~h}$ and $1 / 2 \mathrm{~h}$, respectively, followed by cooling in air and subsequent stabilization at $700^{\circ} \mathrm{C}$ for $2 \mathrm{~h}$. This investigation was undertaken to study the influence of initial microstructure of the alloy on its oxidation behaviour over a wide range of temperature.

\section{Experimental}

The alloy IMI 834 was procured from Imperial Metal Industries, UK, in the form of rods of $18 \mathrm{~mm}$ diameter. The chemical composition of the alloy IMI 834 is recorded in table 1 .

Discs of $2 \mathrm{~mm}$ thickness were cut from the bar using low speed isomet saw. The discs were sealed under vacuum $\left(10^{-3}\right.$ torr) in silica tube with titanium getter. They were solution treated separately in the $\alpha+\beta$ phase field at $1010^{\circ} \mathrm{C}$ for $1 \mathrm{~h}$ and in the $\beta$ phase field at $1080^{\circ} \mathrm{C}$ for $1 / 2 \mathrm{~h}$, respectively and cooled in air (table 2 ).

The vacuum sealed solution treated discs were stabilized by ageing at $700^{\circ} \mathrm{C}$ for $2 \mathrm{~h}$ and cooling in air up to room temperature. These discs were mechanically polished with different grades of coated SiC polishing paper and ultrasonically degreased in acetone and alcohol. Oxidation behaviour of these samples was studied by isothermal thermogravimetry, at $600,650,700,750$ and $800^{\circ} \mathrm{C}$ for $50 \mathrm{~h}$ in laboratory air using CAHN-1000 electro balance. The phases present in the scale were characterized by X-ray diffraction and the morphology of the scale was examined by SEM (JEOL 840A).

Table 2. Heat treatment given to alloy IMI 834.

\begin{tabular}{lcccc}
\hline Designation & $\begin{array}{c}\text { Solution } \\
\text { treatment }\end{array}$ & $\begin{array}{c}\text { Cooling } \\
\text { media }\end{array}$ & $\begin{array}{c}\text { Volume fraction } \\
\text { of primary } \alpha\end{array}$ & Microstructure \\
\hline$(\alpha+\beta)$ ST-AC-A & $1010^{\circ} \mathrm{C}, 1 \mathrm{~h}$ & Air & $11 \cdot 6 \%$ & $\begin{array}{l}\text { Primary } \alpha+\text { transformed } \beta \\
\text { Transformed } \beta \text { with aligned colonies of } \alpha \text { laths }\end{array}$ \\
\hline ST-AC-A & $1080^{\circ} \mathrm{C}, 30$ min & Air & - & Transed \\
\hline
\end{tabular}




\section{Results}

\subsection{Microstructure}

The microstructure of the alloy IMI 834 in the $(\alpha+\beta)$ ST-AC-A and $\beta$ ST-AC-A condition is shown in figure 1. The bimodal nature of the microstructure, with equiaxed primary $\alpha$ and transformed $\beta$ is quite obvious in the $(\alpha+\beta)$ ST-AC-A condition (figure 1a). The volume fraction of primary $\alpha$ was estimated to be $11.6 \%$. Most of the primary $\alpha$ grains may be seen to be associated with prior $\beta$ grain boundaries. However, the distribution of the primary $\alpha$ phase is relatively inhomogeneous. The number density of primary $\alpha$ phase is higher in some regions than in others. The mean intercept length of the primary $\alpha$ phase is $\approx 36 \mu \mathrm{m}$. The transformed $\beta$ grains are found to be coarser than the primary $\alpha$ grains and their mean intercept length is $130 \mu$ (figure 1a). The microstructure of the transformed $\beta$ consists of $\alpha$ platelets; with thin layer of $\beta$ phase retained between them.

However, as expected the microstructure of the $\beta$ STAC-A material consists of fully lamellar $\alpha$ platelets and retained $\beta$. Further, there is absence of the primary $\alpha$ phase in this condition. The mean intercept length of prior $\beta$ grains is $530 \mu \mathrm{m}$ (figure $1 \mathrm{~b}$ ).

The oxidation behaviour is evaluated in terms of weight gain with time, at various temperatures, for both $\alpha+\beta$ as well as $\beta$ heat treated conditions (figure 2). It may be seen
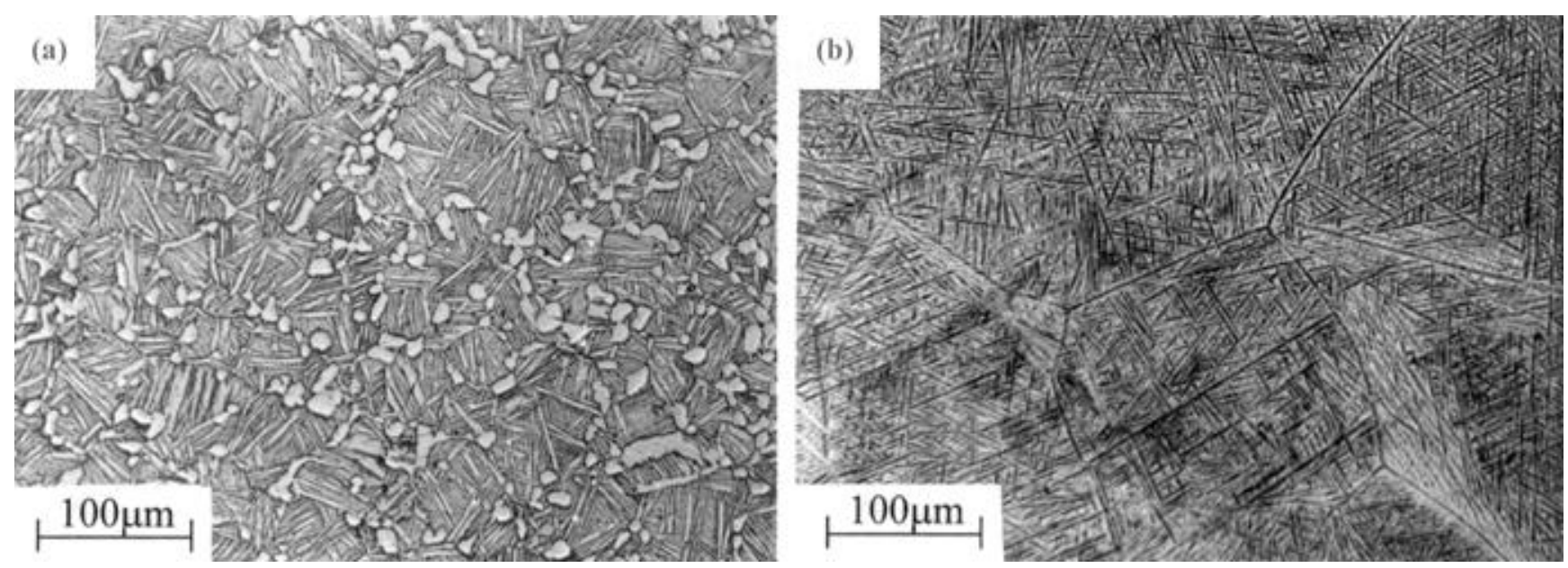

Figure 1. Optical micrographs for (a) $(\alpha+\beta)$ ST-AC-A and (b) $\beta$ ST-AC-A conditions.

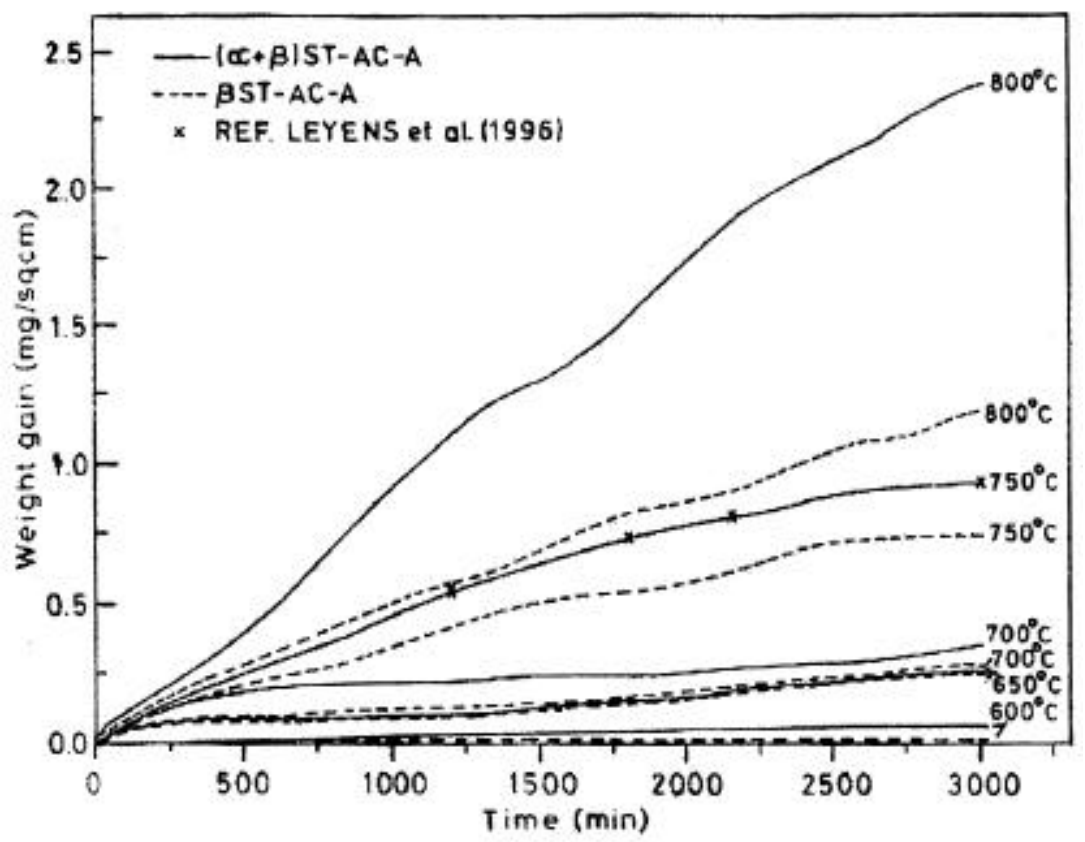

Figure 2. Variation of weight gain with time of oxidation. 
that in the $\beta \mathrm{ST}-\mathrm{AC}-\mathrm{A}$ condition the weight gain is relatively less than that in the $(\alpha+\beta)$ ST $-\mathrm{AC}-\mathrm{A}$, at all temperatures studied.

The activation energy for the process of oxidation in the $(\alpha+\beta)$ and $\beta$ treated conditions was estimated to be $184 \mathrm{~kJ} / \mathrm{mole}$ and $223 \mathrm{~kJ} / \mathrm{mole}$, respectively (figure 3). Thus it is obvious that activation energy is higher for the $\beta$ treated condition than that of the $\alpha+\beta$ treated one.

The rate constants obtained from the plot of log weight gain (vs) $\log t$ (figure 4) are recorded in table 3 . It may be seen that the kinetic laws in both the heat treated conditions follow mostly parabolic behaviour at and above $650^{\circ} \mathrm{C}$, however, at $600^{\circ} \mathrm{C}$ the behaviour is nearly linear.

\subsection{Formation of various phases and morphology} of the scale

The major phases in the scale, resulting from oxidation, at different temperatures, were characterized by XRD (figure 5) (table 4). It may be noted that in addition to

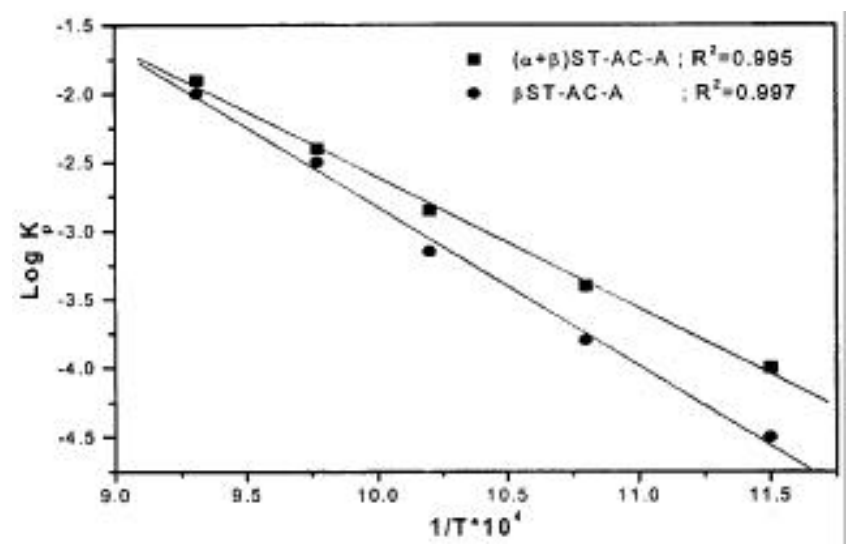

Figure 3. Arrheneous plot.

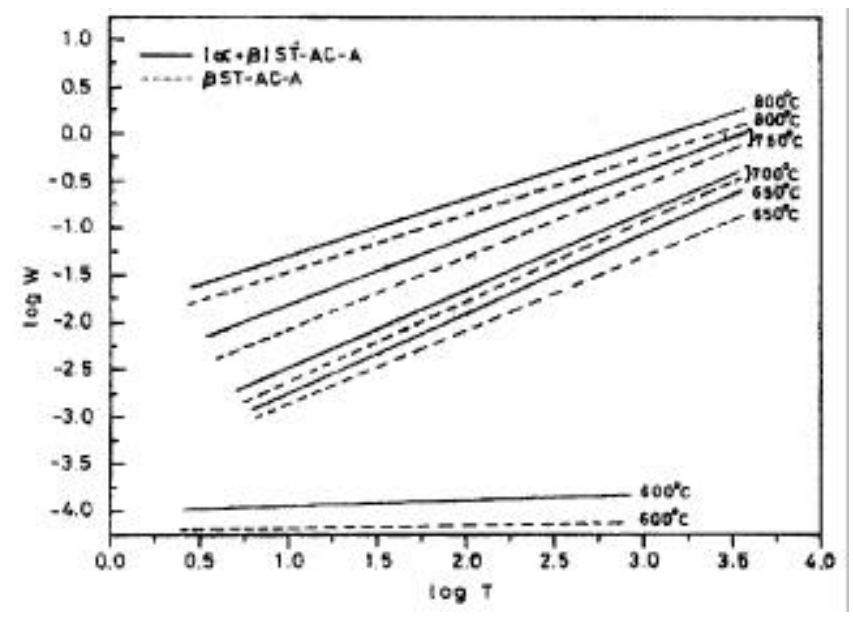

Figure 4. Variation of weight gain with time of oxidation at different temperatures. titanium oxide, $\mathrm{TiO}_{2}$, there is also the presence of titanium aluminium nitride $\left(\mathrm{Ti}_{3} \mathrm{AlN}\right)$ in the specimens oxidized at elevated temperatures of $750^{\circ} \mathrm{C}$ and $800^{\circ} \mathrm{C}$. Weak reflections of $\alpha$-alumina were also detected, however, these are not indicated in the figure for the sake of clarity.

The morphology of the scales formed on the $\alpha+\beta$ and $\beta$ treated samples oxidized at 700 and $800^{\circ} \mathrm{C}$ is shown by the SEM micrographs in figure 6. It may be seen that the scales formed on the $\beta$ treated samples are relatively more uniform and compact. The granules in the scale formed at $800^{\circ} \mathrm{C}$ are seen to be finer than those formed at $700^{\circ} \mathrm{C}$.

It may be seen that the ratio of $\mathrm{Ti}_{3} \mathrm{AlN}$ to $\mathrm{TiO}_{2}$ (table $6)$ is higher in the $(\alpha+\beta)$ ST-AC-A condition, both at $750^{\circ} \mathrm{C}$ and in particular at $800^{\circ} \mathrm{C}$. Thus the higher rate of oxidation observed in the $(\alpha+\beta)$ ST $-\mathrm{AC}-\mathrm{A}$ condition than in the $\beta$ ST-AC-A may be understood.

The variation of weight gain at different temperatures from $600-800^{\circ} \mathrm{C}$, for $10,30,50 \mathrm{~h}$ for $(\alpha+\beta) \mathrm{ST}-\mathrm{AC}-\mathrm{A}$ and $\beta \mathrm{ST}-\mathrm{AC}-\mathrm{A}$ is shown in figures $7(\mathrm{a})$ and (b), respectively.

It may be seen that while the data points extrapolated corresponding to oxidation temperature of $600^{\circ} \mathrm{C}$ lie on the curves for $\beta \mathrm{ST}-\mathrm{AC}-\mathrm{A}$ condition, but there is some deviation in the case of $(\alpha+\beta) \mathrm{ST}-\mathrm{AC}-\mathrm{A}$ condition.

\section{Discussion}

It is obvious from the weight gain curves of the alloy IMI 834 in the $(\alpha+\beta)$ ST-AC-A and $\beta$ ST $-A C-A$ condition, over the range of temperature from $600-800^{\circ} \mathrm{C}$, that there is significant influence of the temperature of oxidation and the initial microstructure of the alloy on its oxidation behaviour. At $600^{\circ} \mathrm{C}$, there is very little weight gain in the $(\alpha+\beta) \mathrm{ST}-\mathrm{AC}-\mathrm{A}$ condition and it is almost negligible in the $\beta \mathrm{ST}-\mathrm{AC}-\mathrm{A}$ condition. However, above $600^{\circ} \mathrm{C}$ there is progressive increase in weight gain with rise in temperature.

In general, the levels of weight gain curves are higher for the $\alpha+\beta$ treated condition than those of the $\beta$ treated one, over the entire range of temperature investigated. One of the most likely cause of this behaviour may be the highly coarse grain size of the $\beta$ treated material than that of the $\alpha+\beta$ treated one and consequently much lower ratio

Table 3. Values of the exponent ' $n$ ' in the generalized rate expression, at various temperatures.

\begin{tabular}{lcc}
\hline \multirow{2}{*}{$\begin{array}{l}\text { Oxidation } \\
\text { temperature }\left({ }^{\circ} \mathrm{C}\right)\end{array}$} & \multicolumn{2}{c}{$n$} \\
\cline { 2 - 3 } 600 & 0.85 & $\beta$ ST-AC-A \\
\hline 650 & 0.46 & 0.90 \\
700 & 0.48 & 0.45 \\
750 & 0.59 & 0.47 \\
800 & 0.70 & 0.54 \\
\hline
\end{tabular}


of the grain boundary area to the total surface area in the $\beta$ treated condition.

Further, it may be noted that there is relatively more uniform distribution of the alloying elements, particularly of aluminium, a strong oxide forming element in the $\beta$ treated condition than that in the $\alpha+\beta$ treated one, in which the concentration of $\mathrm{Al}$ is relatively higher in the primary $\alpha$ phase than that in the transformed $\beta$. Thus the scale of $\mathrm{Al}_{2} \mathrm{O}_{3}$ formed is likely to be more uniform in the $\beta$ treated condition than that in the $\alpha+\beta$ treated one. Leyens et al (1996) studied oxidation behaviour of the alloy IMI 834 at $750^{\circ} \mathrm{C}$, in three different microstructural conditions, viz. globular, two phase $(\alpha+\beta)$ and lamellar; resulting from solution treatment at $990^{\circ} \mathrm{C}, 1030^{\circ} \mathrm{C}$, and $1070^{\circ} \mathrm{C}$, respectively and cooling in air. They observed that weight gain was lower in the $\beta$ treated condition than that in the $\alpha+\beta$ treated one. Thus the observations made on oxidation behaviour of the alloy 834 , in the present investigation are in agreement with those made earlier by Leyens et al (1996). Leyens et al examined the distribution of $\mathrm{Ti}$ and also the different alloying elements like Al, $\mathrm{Sn}, \mathrm{Nb}$ along with oxygen in the scale, resulting from oxidation at $750^{\circ} \mathrm{C}$ for $100 \mathrm{~h}$ and established that there was almost uniform distribution of $\mathrm{Ti}$ and the alloying elements in the scale and the substrate except that of aluminium, which was higher in concentration in the oxidized layer. Aluminium is known to form protective $\mathrm{Al}_{2} \mathrm{O}_{3}$ on the surface. It may, however, be noted that $\simeq 50 \%$
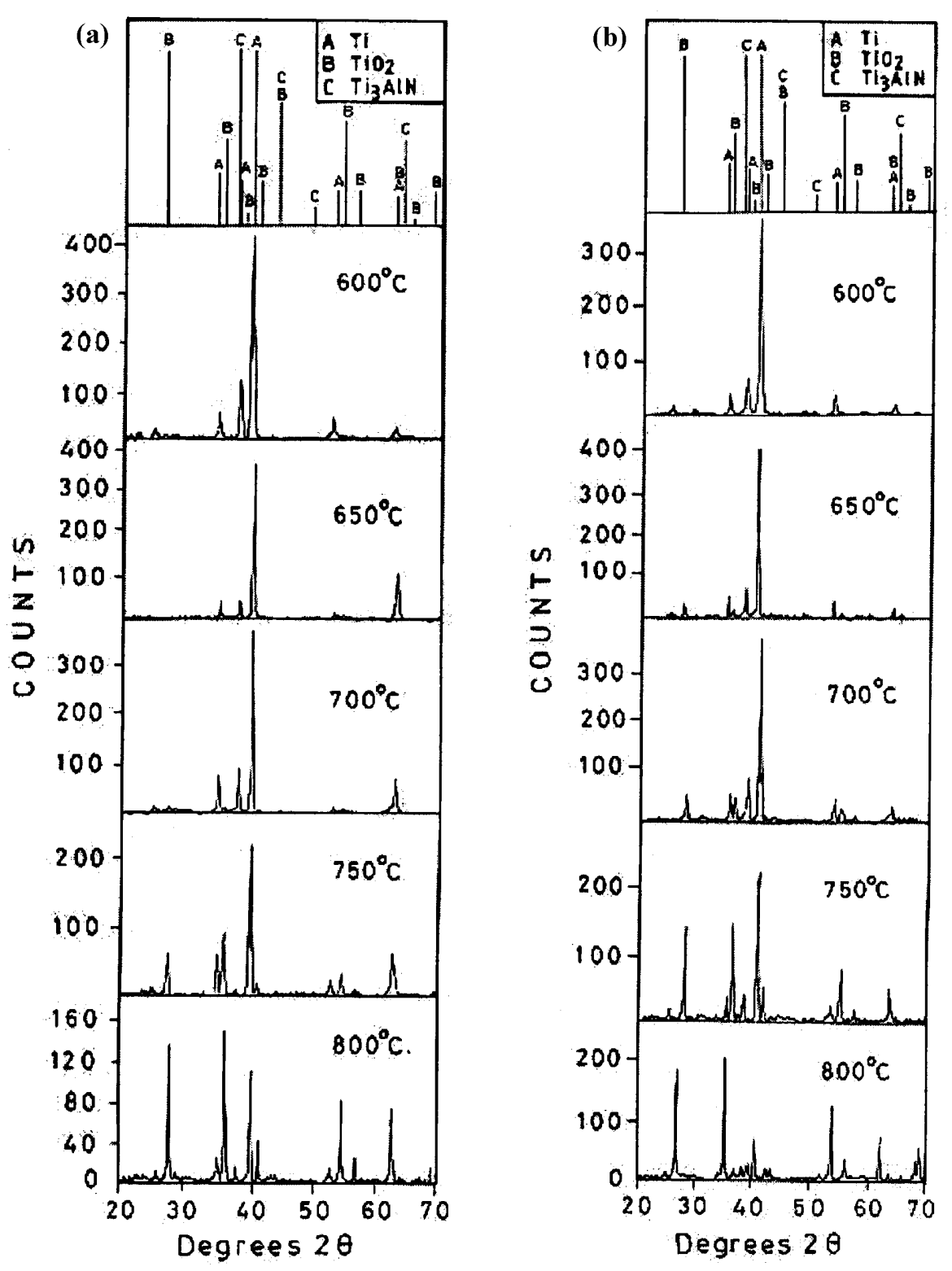

Figure 5. XRD patterns for the (a) $(\alpha+\beta)$ ST-AC-A sample and (b) $\beta$ ST-AC-A sample, oxidized at different temperatures for $50 \mathrm{~h}$. 
$\mathrm{Al}$ is required for complete coverage of the outer surface by $\mathrm{Al}_{2} \mathrm{O}_{3}$ like that in the intermetallic compound $\mathrm{Ti}-\mathrm{Al}$ according to Shimizu et al (1992). Thus there is less probability of full protection of the alloy 834 by $\mathrm{Al}_{2} \mathrm{O}_{3}$. Further, there would be variation in distribution of $\mathrm{Al}_{2} \mathrm{O}_{3}$ on

Table 4. Various phases in the specimens following oxidation at different temperatures.

\begin{tabular}{lcl}
\hline Heat treatment & Temperature $\left({ }^{\circ} \mathrm{C}\right)$ & Phases present \\
\hline$(\alpha+\beta)$ ST-AC-A & 600 & $\mathrm{Ti}, \mathrm{TiO}_{2}$ \\
& 650 & $\mathrm{Ti}, \mathrm{TiO}_{2}$ \\
& 700 & $\mathrm{Ti}, \mathrm{TiO}_{2}$ \\
& 750 & $\mathrm{Ti}, \mathrm{TiO}_{2}, \mathrm{Ti}_{3} \mathrm{AlN}$ \\
$\beta$ ST-AC-A & 800 & $\mathrm{Ti}, \mathrm{TiO}_{2}, \mathrm{Ti}_{3} \mathrm{AlN}$ \\
& 600 & $\mathrm{Ti}, \mathrm{TiO}_{2}$ \\
& 650 & $\mathrm{Ti}, \mathrm{TiO}_{2}$ \\
& 700 & $\mathrm{Ti}, \mathrm{TiO}_{2}$ \\
& 750 & $\mathrm{Ti}, \mathrm{TiO}_{2}, \mathrm{Ti}_{3} \mathrm{AlN}$ \\
& 800 & $\mathrm{Ti}, \mathrm{TiO}_{2}, \mathrm{Ti}_{3} \mathrm{AlN}$ \\
\hline
\end{tabular}
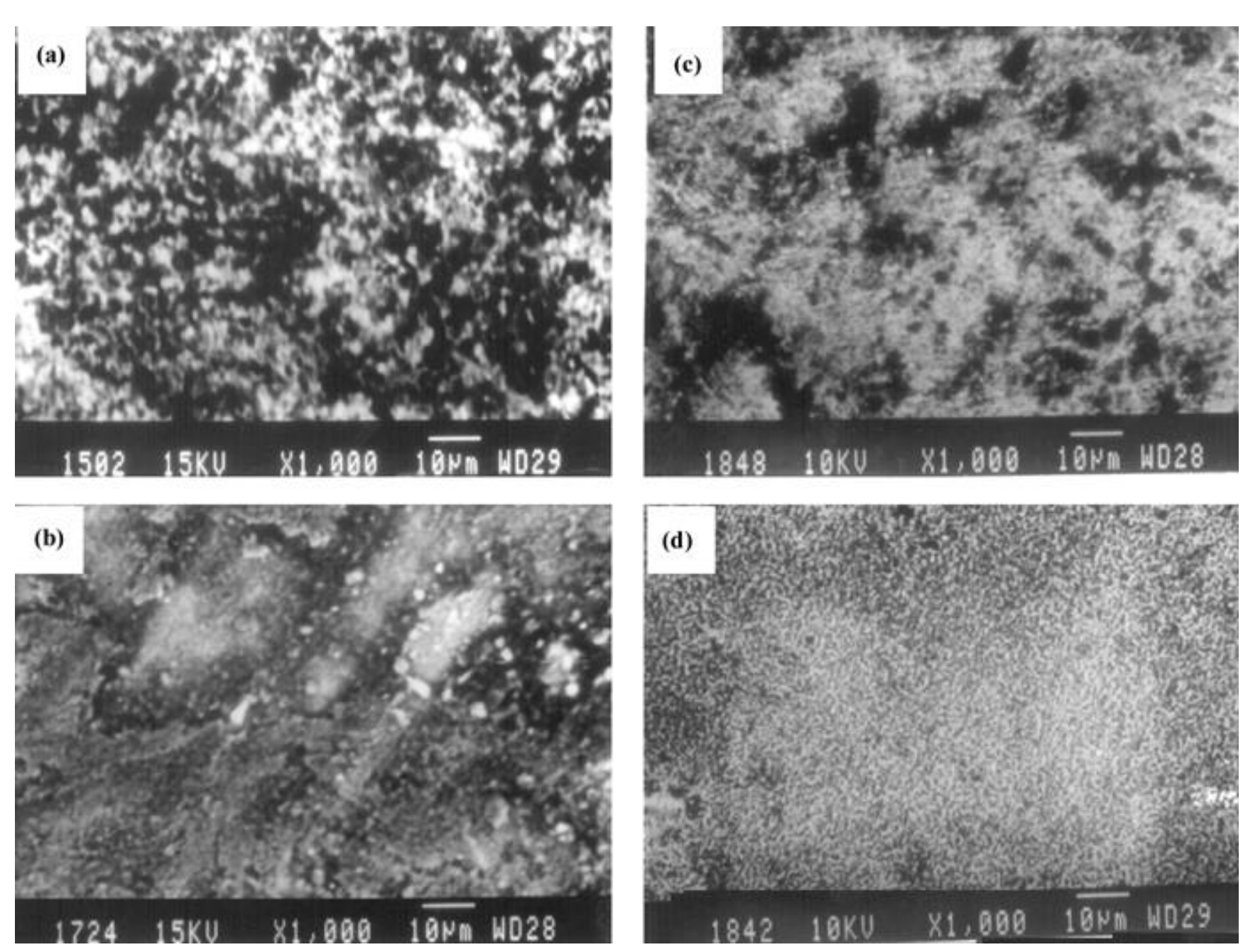

the surface because of the difference in microstructure of the $\alpha+\beta$ and $\beta$ treated samples and consequent variation in $\mathrm{Al}$ content due to the partitioning effect. The solvus temperature of $\mathrm{Ti}_{3} \mathrm{Al}$ in the primary $\alpha$ is $795^{\circ} \mathrm{C}$ and in the transformed $\beta, 735^{\circ} \mathrm{C}$. Thus more amount of $\mathrm{Ti}_{3} \mathrm{Al}$ is likely to be present at $800^{\circ} \mathrm{C}$ in the $(\alpha+\beta) \mathrm{ST}-\mathrm{AC}-\mathrm{A}$ condition, and hence there is relatively less possibility of protection by formation of $\mathrm{Al}_{2} \mathrm{O}_{3}$ due to less amount of free Al available.

It is obvious from the weight gain curves (figure 2) that the scales formed on the alloy IMI 834 are strongly adherent and did not spall up to $50 \mathrm{~h}$ of oxidation even at $800^{\circ} \mathrm{C}$. These observations are in agreement with those made earlier by Leyens et al (1996). They observed no spalling of scale formed at $750^{\circ} \mathrm{C}$ even after $100 \mathrm{~h}$ of oxidation. The adherence of the oxide scale has been found to be affected by the content of nitride phase $\left(\mathrm{Ti}_{3} \mathrm{AlN}\right)$ formed at elevated temperatures of $750^{\circ} \mathrm{C}$ and $800^{\circ} \mathrm{C}$. It has been established by Leyens et al (1996) from their oxidation studies on the alloys IMI 834 and Ti 1100 that the adhe-

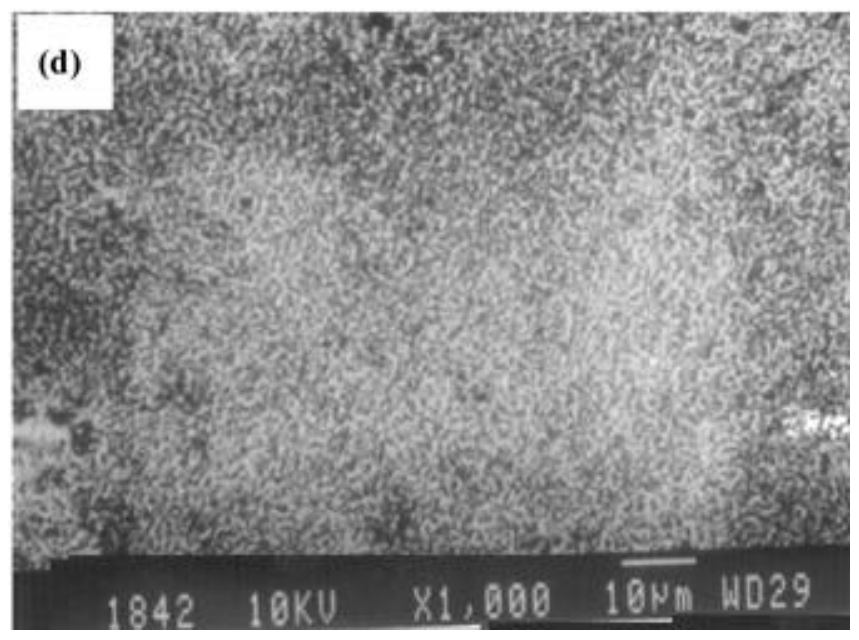

Figure 6. SEM micrographs showing surface morphology of the samples oxidized at $700^{\circ} \mathrm{C}$ and $800^{\circ} \mathrm{C}$ for $50 \mathrm{~h}$. $((\alpha+\beta) \mathrm{ST}-\mathrm{AC}-\mathrm{A}$ : (a) $700^{\circ} \mathrm{C}$, (b) $800^{\circ} \mathrm{C}$; $\beta \mathrm{ST}-\mathrm{AC}-\mathrm{A}$ : (c) $700^{\circ} \mathrm{C}$ and (d) $800^{\circ} \mathrm{C}$ ). 
rence of the oxide scale formed decreases with increase in the $\mathrm{Ti}_{3} \mathrm{AlN}$ content, in the scale. It is obvious from the XRD results (figure 5) and the data in table 3, that while there is presence of essentially $\mathrm{TiO}_{2}$ in the specimens oxidized at 600,650 and $700^{\circ} \mathrm{C}$, in addition there is also presence of the phase $\mathrm{Ti}_{3} \mathrm{AlN}$ in the specimens oxidized

Table 5. Ratio of $100 \%$ reflection of $\mathrm{Ti}_{3} \mathrm{AlN}$ to $\mathrm{TiO}_{2}$.

\begin{tabular}{lcc}
\hline & \multicolumn{2}{c}{ Oxidation temperature } \\
\cline { 2 - 3 } Heat treatment & $750^{\circ} \mathrm{C}$ & $800^{\circ} \mathrm{C}$ \\
\hline$(\alpha+\beta)$ ST-AC-A & 1.06 & 1.20 \\
$\beta$ ST-AC-A & 1.03 & 1.08 \\
\hline
\end{tabular}

Table 6. Weight gain $(\mathrm{mg} / \mathrm{sq} \mathrm{cm})$ at $600^{\circ} \mathrm{C}$ after $50 \mathrm{~h}$.

\begin{tabular}{lcc}
\hline Heat treatment & Experimental & Extrapolated \\
\hline$(\alpha+\beta)$ ST-AC-A & 0.07 & 0.03 \\
$\beta$ ST-AC-A & 0.01 & 0.01 \\
\hline
\end{tabular}
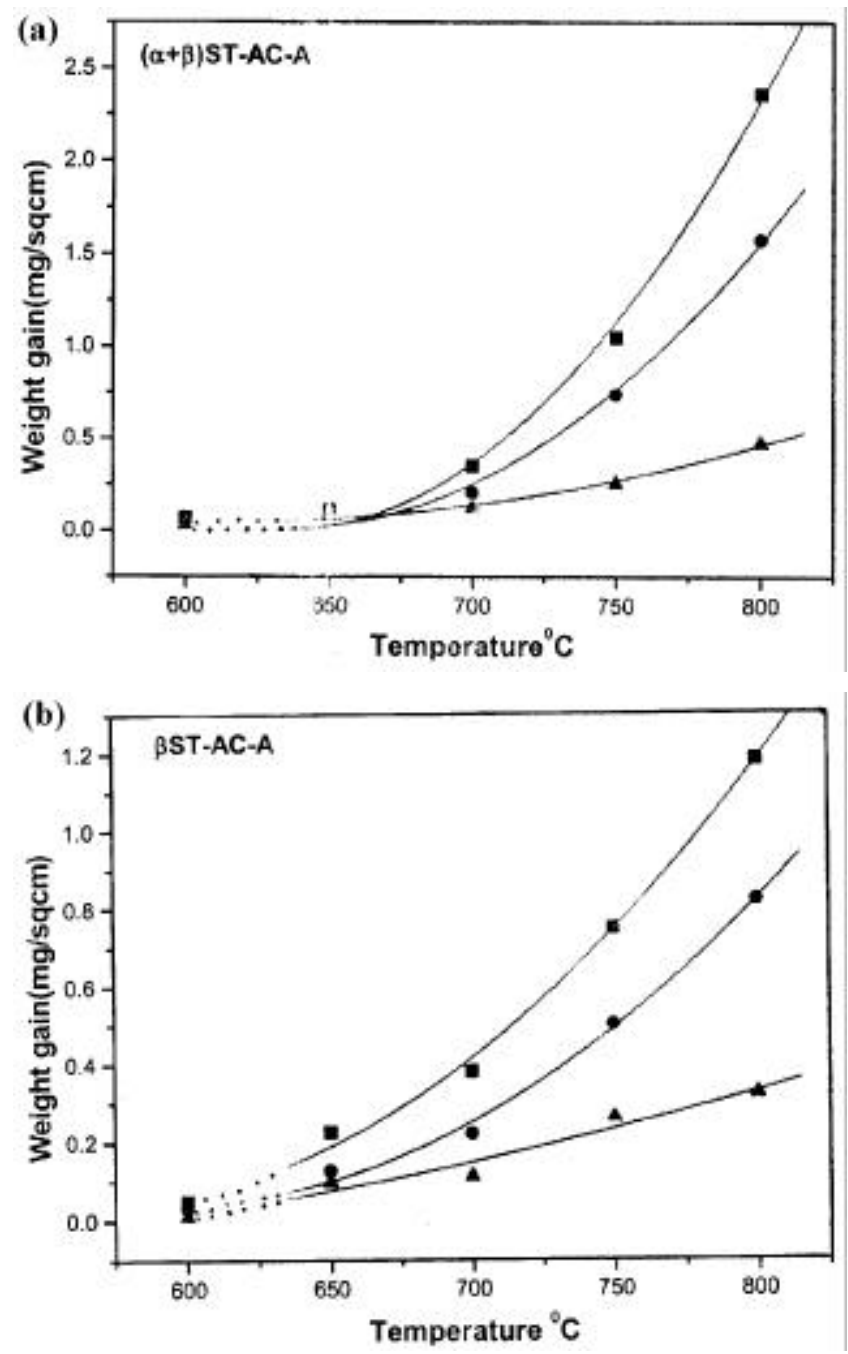

Figures 7a-b. Variation of weight gain at different temperatures. at higher temperatures of $750^{\circ} \mathrm{C}$ and $800^{\circ} \mathrm{C}$. It is relevant to mention here that there were very weak reflections of $\mathrm{Al}_{2} \mathrm{O}_{3}$ in the oxidized specimens and hence the presence of $\mathrm{Al}_{2} \mathrm{O}_{3}$ in the scale is quite likely, though in small quantity. Thus the relatively poor oxidation resistance of the alloy 834 at $750^{\circ} \mathrm{C}$ and $800^{\circ} \mathrm{C}$ may be attributed to presence of the phase $\mathrm{Ti}_{3} \mathrm{AlN}$ which is known to have adverse influence on adherence of the oxide scale. The formation of $\mathrm{Ti}_{3} \mathrm{AlN}$ phase at the interface of the substrate and the oxide scale must be controlled essentially by diffusion of nitrogen from air, through the scale.

Oxidation of the alloy IMI 834 follows a parabolic behaviour and the rate constants increase with increase in temperature in both the heat-treated conditions. However, at $600^{\circ} \mathrm{C}$, it is very close to linear behaviour in both the heat treated conditions. It may be seen from surface morphology (figure 6) of the oxidized specimens that there is more uniform distribution of the oxide granules and better coverage of the surface in the $\beta \mathrm{ST}-\mathrm{AC}-\mathrm{A}$ condition than that in the $(\alpha+\beta) \mathrm{ST}-\mathrm{AC}-\mathrm{A}$. Further, the granules formed in the $\beta \mathrm{ST}-\mathrm{AC}-\mathrm{A}$ are relatively finer.

Zhang et al (2002) reported the values of activation energy of oxidation and diffusion in various titanium alloys and the values of activation energy lie in the range of $183 \mathrm{~kJ} / \mathrm{mole}$ to $299 \mathrm{~kJ} / \mathrm{mole}$ depending upon the alloy composition. The values of activation energy of diffusion of oxygen in $\mathrm{TiO}_{2}$, Ti diffusion in $\mathrm{TiO}_{2}$, oxygen fast diffusion path in $\mathrm{Al}_{2} \mathrm{O}_{3}$ lie in the range of $234 \mathrm{~kJ} / \mathrm{mole}$ to $257 \mathrm{~kJ} / \mathrm{mole}$. The activation energy values in the present investigation are $184 \mathrm{~kJ} / \mathrm{mole}$ for $(\alpha+\beta) \mathrm{ST}-\mathrm{AC}-\mathrm{A}$ condition and $223 \mathrm{~kJ} / \mathrm{mole}$ for $\beta \mathrm{ST}-\mathrm{AC}-\mathrm{A}$ condition, respectively. However, it is difficult to ascertain the actual process of oxidation.

\section{Conclusions}

Following conclusions may be drawn from the present investigation:

(I) Oxidation resistance of the alloy IMI 834 was better for the $\beta$ ST $-\mathrm{AC}-\mathrm{A}$ condition than that of the $(\alpha+\beta) \mathrm{ST}-$ $\mathrm{AC}-\mathrm{A}$ condition, at all temperatures from 600 to $800^{\circ} \mathrm{C}$.

(II) Oxidation of the alloy 834 at $600^{\circ} \mathrm{C}$ is very little in both the heat treated conditions and it increases with test temperature.

(III) Decrease in oxidation resistance at elevated temperatures of 750 and $800^{\circ} \mathrm{C}$ may be due to the detrimental influence of $\mathrm{Ti}_{3} \mathrm{AlN}$ on scale adherence, formed at these temperatures.

(IV) Activation energy for $(\alpha+\beta) \mathrm{ST}-\mathrm{AC}-\mathrm{A}$ and $\beta \mathrm{ST}-$ AC-A conditions are evaluated to be $184 \mathrm{~kJ} / \mathrm{mole}$ and $223 \mathrm{~kJ} /$ mole, respectively.

\section{Acknowledgements}

Authors express their sincere thanks to Prof. Mankhand for providing laboratory facilities. Authors also express their thanks to Dr Mandal for XRD analysis. 


\section{References}

Andreeva N 2003 Corrosion resistance of titanium (USA: Titanium Metals Corporation) (Timet.com)

Bania P J 1988 Low temperature oxidation of selected titanium alloys, Proc. sixth world conf. on titanium (Les Ulis: Societe Francaise de Metallurgie) p. 825

Becker S, Rahmel A, Schorr M and Schutze M 1992 Oxidation Metals 38425

Champin B 1980 J. Less Common Met. 69163

Coddet C, Ramoul K, Chaze and Beranger G 1980 Oxidation of titanium base alloys for application in turbines, Proc. 4th world conf. on titanium (Warrendale: The Metallurgical Society of AIME) p. 2755

Holt-Walton and Hill 2002 Tatanium alloys for aero engine and air frame applications, An engineers resource, Azom.com
Leyens M, Peters M and Kaysser W A 1996 Mater. Sci. \& Technol. 12213

Liu Z and Welsch G 1988 Met. Trans. A19 527

Magdalena M 1998 Kinetic behaviour of the titanium alloys Ti6Al4V and Ti6Al5Zr0.5Mo0.25Si in air and oxygen at a temperature range of $400-600^{\circ} \mathrm{C}$, Summary report

Simon D, Devillers B and Bardolle J 1980 Study of the oxidation of titanium by microgravimetry and electron spectroscopy at elevated temperatures and low pressures, Proc. 4th world conf. on titanium (Warrendale: The Metallurgical Society of AIME) p. 2859

Shimizu T, Iikubo T and Isobe S 1992 Mater. Sci. \& Engg. A153 602

Wiedemann K E, Shenoy R N and Unnam J 1987 Met. Trans. A18 1503

Zhang Erlin, Zeng Gang and Zeng Songyan 2002 Scripta Materialia 46811 